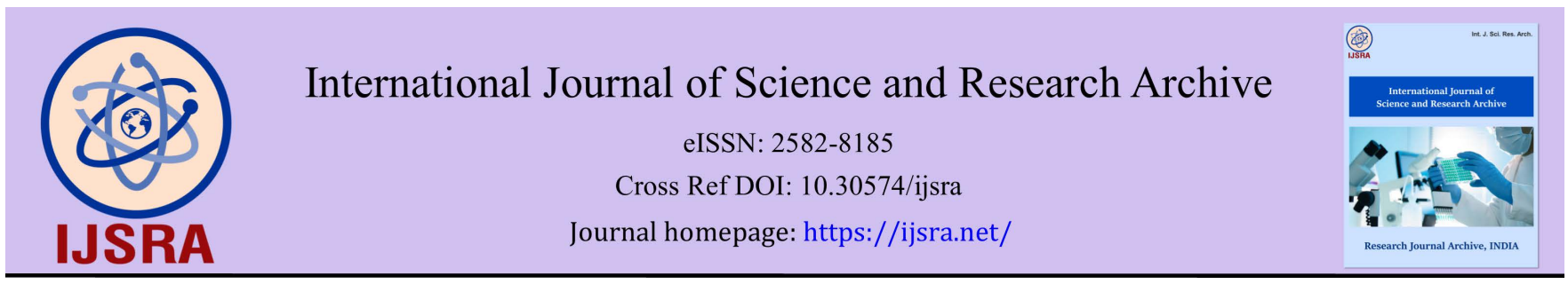

(RESEARCH ARTICLE)

\title{
Determination of the effect of co-administration of Andrographis paniculata leaves and Zingiber officinale rhizoids on serum liver enzymes in normal Albino wistar rats
}

\author{
Nnamso Effiong Essien *, Nkereuwem Udo Nyah, Promise-Godfavour Mfon, Ekaertte Joseph Tom \\ Department of Science Technology, Akwa Ibom State Polytechnic, Ikot Osurua, Ikot Ekpene Akwa Ibom State, Nigeria.
}

International Journal of Science and Research Archive, 2021, 02(02), 225-230

Publication history: Received on 17 April 2021; revised on 31 May 2021; accepted on 03 June 2021

Article DOI: https://doi.org/10.30574/ijsra.2021.2.2.0075

\begin{abstract}
The effect of administration of ethanol extracts of Andrographis paniculata leaves and Zingiber officinale rhizoids on serum liver enzymes (ASP, ALP and ALT) in normal male albino wistar rats, weighing 113-233g was evaluated. Twentyfive (25) animals were randomly assigned five groups of five rats each. Groups 1, 2, 3 and 4 were treated with $100 \mathrm{mg} / \mathrm{kg}$, $200 \mathrm{mg} / \mathrm{kg}, 300 \mathrm{mg} / \mathrm{kg}$ and $400 \mathrm{mg} / \mathrm{kg}$ respectively of Andrographis paniculata leaves and Zingiber officinale rhizoids extracts. Group 5 (control) was not treated. Both treated and control animals were fed with commercial rat mash and water throughout three (3) weeks of experiments. At the end of the 21 days, significant decrease (P> 0.05 ) in serum AST level was recorded in treated groups $1,2,3$ and 4 compared with the control. Significant decrease (P>0.05) in serum ALP level was recorded in group 4 when compared with control. However, serum ALP level recorded significant increase in group 4 compared with group $3(\mathrm{P}>0.05)$. The results of this research work signified that administration of ethanol extracts of Andrographis paniculata leaves and Zingiber officinale rhizoids possessed no marked effects on the liver enzymes since variations in the levels of the enzymes were within their normal serum ranges.
\end{abstract}

Keywords: Liver enzymes; Albino wistar rats; Andrographis paniculata; Zingiber officinale

\section{Introduction}

Herbs and plants have been in use as a source of therapeutic compounds in traditional medical system since ancient times [1]. Medicinal plants play important role in traditional health care systems as well as in international herbal and pharmaceutical markets. Medicinal value of these plants lies in some chemical substances that produce a definite physiological action on the human body [2]. It is estimated that about two third of population relies heavily on traditional practitioners and medicinal plants to meet primary healthcare need [3]. As the result of numerous problems associated with orthodox drugs, many species are now being revealed by researchers based on variation in plant species and their therapeutic chemical principles. One of such plant species is Andrographis paniculata used in ancient oriental and Ayurvedic medicine. The genus Andrographis which belongs to Ancanthaceae family comprises 40 species, only few are popular for their uses in folk medicine (or assorted health concerns). Of these few, Anarographis peniculata, commonly known as "King of bitters" is an annual plant from Southern England, Scandinavia, across Central Europe to Southwest and East Asia and Japan [4].

Andrographis is used for digestive complaints including diarrhoea, constipation, intestinal gas and enlarged liver, jaundice and liver damage due to medication for infection including leprosy, pneumonia, tuberculosis, gonorrhea, syphilis, malaria, leptospirosis, rabies and skin conditions such as wound healing, cancer etc. [5- 6] It is also used as astringent, bacterial killing agent, pain killer, fever reducer and treatment for worm and insects bites, loss of appetite, kidney problems (pyelonephritis), haemorrhoids and inherited condition called familial Mediterranean fever [5].

\footnotetext{
* Corresponding author: Essien NE

Department of Science Technology, Akwa Ibom State Polytechnic, Ikot Osurua, Ikot Ekpene Akwa Ibom State, Nigeria.

Copyright (c) 2021 Author(s) retain the copyright of this article. This article is published under the terms of the Creative Commons Attribution Liscense 4.0.
} 
International Journal of Science and Research Archive, 2021, 02(02), 225-230

Studies have revealed that Zingiber officinale (Zingiberaceae) is an important plant with several ethnomedicinal and nutritional values, therefore, used extensively worldwide as a spice, flavouring agent and herbal remedy [7].

Traditionally, Zingiber officinale is used in Ayurveda Siddha, Chinese, Arabian, Africans, Caribbean and many other medicinal systems to cure a variety of diseases viz; nausea, vomiting, asthma, cough, palpitation, inflammation, dyspepsia, loss of appetite, constipation, indigestion and pains [8].

In last few decades, Zingiber officinale is extensively studied for its medicinal properties by advanced scientific techniques and a variety of bioactive compounds have been isolated from different parts of the plant and were analyzed pharmacologically. The plant is reported for antimicrobial activity and anticancer activity [9], antioxidant, antidiabetic, nephroprotective, hepatoprotective, larvicidal, analgesic, anti-inflammatory, and immunomodulatory activities [10].

\section{Material and methods}

\subsection{Collection of the Plant Samples}

The fresh leaves of Andrographis paniculata were collected in June, 2019 from the botanical garden in Akwa Ibom State Polytechnic, Ikot Osurua, Ikot Ekpene Local Government Area. Z. officinale rhizoids were bought from Oto market from the above Local Government Area both in Akwa Ibom State. The two samples were identified and authenticated by a Taxonomist in the Department of Botany, University of Uyo, Akwa Ibom State, Nigeria and were later taken to the Biochemistry Laboratory in Akwa Ibom State Polytechnic, Ikot Osurua, Ikot Ekpene for preparation and use in the research.

\subsection{Preparation of the Plant Samples}

Andrographis peniculata leaves were plucked from the stem and Zingiber officinale rhizoids were scrapped with the aid of a knife to remove the bark. Both samples were separately washed in a clean water to remove debris, shred and were air- dried for 48 hours under shed. The dried samples were ground separately to powdery form using an electric blender and were stored in air-tight containers and labeled correctly. About $170 \mathrm{~kg}$ of powdered Andrographis paniculata was macerated in $3500 \mathrm{ml}$ of $70 \%$ ethanol and $185 \mathrm{~kg}$ of powdered Zingiber officinale was macerated in $2500 \mathrm{ml}$ of $70 \%$ ethanol for 72 hours respectively at room temperature $\left(25^{\circ} \mathrm{C}\right)$. The mixtures were then filtered separately using Whatman's No I filter paper over a funnel. The filtrates were separately concentrated in water bath at $40-50{ }^{\circ} \mathrm{C}$ for three consecutive days to get the slurry form of the extracts. They were preserved in a refrigerator at $4{ }^{\circ} \mathrm{C}$ for further use.

\subsection{Experimental Design, Grouping and Treatment of the Animals}

Twenty-five (25) albino Wister rats weighing (113-233g) of male sex were obtained from the disease-free stock of the animal house, Biochemistry Unit, Department of Science Technology, Akwa Ibom State Polytechnic, Ikot Osurua, and were randomly assigned five (5) groups of five rats each. They were housed in wooden cages under standard conditions for acclimatization for one week in the animal house before the commencement of the experiment. Each group was weighed to obtain the mean body weight. Group 1 received a combined extract of Andrographis paniculata (50mg) and Zingiber officinale (50mg). Group 2 received a combined extract of Andrographis paniculata (100mg) and Zingiber officinale (100mg). Group 3 received a combined extract of Andrographis paniculata (150mg) and Zingiber officinale (150mg). Group 4 received a combined extract of Andrographis paniculata (200mg) and Zingiber officinale (200mg). Group 5 was the normal control without extract administration but were fed with normal rat mash and distilled water for three weeks. The treated groups were equally fed with rat mash and distilled water throughout the period of treatment. The extracts were administered daily through oral route. Good hygiene was maintained by constant cleaning and removal of faeces and spilled feed from cages daily.

\subsection{Collection of Blood Sample and Preservation of Serum}

After 21 days ( 3 weeks) of extracts administration and feeding, the animals were subjected to overnight fast, then they were anaesthetized with chloroform vapour and were sacrificed by dissecting medioventrically and the blood sample collected through cardiac puncture by means of syringe and needle into well labeled anticoagulant (EDTA) bottles and gently shaken and allowed to stand for 1 hour after which they were centrifuged at 4,000 RPM for 10minutes to separate serum from the blood cells.

The serum obtained was used for the determination of liver enzymes (ALP, ALT and AST). 


\subsection{Determination of serum Aspartate Amino Transferase (AST) Level}

\subsubsection{Principle}

This was done using the method of Baluna and Kinghorn [11]. This principle is based on transamination reaction between L-aspartate and L-glutamate catalyzed by AST. It is measured by monitoring the concentration of oxaloacetate hydrazine formed with 2, 4-dinitrophenylhydrazine.

$$
\alpha \text { - Oxoglutarate }+\mathrm{L}-\text { aspartate } \stackrel{\text { Got }}{\rightarrow} \mathrm{L}-\text { glutamate }+ \text { oxaloacetate }
$$

\subsubsection{Procedure}

To two test tubes labeled blank and samples, $0.1 \mathrm{ml}$ of distilled water and $0.1 \mathrm{ml}$ of Serum samples were measured into the test tubes respectively, and $0.5 \mathrm{ml}$ of the substrate reagent $\left(\mathrm{R}_{1}\right)$ was added to each of the test tubes which was mixed and incubated for exactly 30 minutes at $37^{\circ} \mathrm{C}$. Then $0.5 \mathrm{ml}$ of 2,4 dinitrophenyl hydrazine solution $\left(\mathrm{R}_{2}\right)$ was mixed and allowed to stand for 20 minutes at $20-25^{\circ} \mathrm{C}$ and finally $5 \mathrm{ml}$ sodium hydroxide $(0.4 \mathrm{M})$ was added to each test tubes, mixed and the concentration was obtained by reading the chart provided by the manufacturer.

\subsection{Determination of serum Alkaline Phosphatase (ALP) Level}

\subsubsection{Principle}

Alkaline Phosphatase in serum is determined using the method described by Englehant [12], using Randox laboratory kit which employs the fixed procedure for the determination of enzymes.

$$
\mathrm{p}-\text { nitrophenylphosphate }+\mathrm{H} 2 \mathrm{O} \stackrel{\text { ALP }}{\rightarrow} \text { phosphate }+\mathrm{P}-\text { nitrophenol }
$$

\subsubsection{Procedure}

To three test tubes labeled blank, sample and control, $0.05 \mathrm{ml}$ of distilled water, $0.05 \mathrm{ml}$ of standard and $0.05 \mathrm{ml}$ of the control sera were measured into each tubes respectively. Then, $0.05 \mathrm{ml}$ of alkaline phosphatase substrate was mixed and incubated for 10 minutes at $37^{\circ} \mathrm{C}$. Thereafter, $2.5 \mathrm{ml}$ of alkaline phosphatase colour developer was added to each tube and mixed. Absorbance was read using spectrophotometer at wavelength of 590nm. Concentration of samples were calculated using:

$$
\frac{\text { Absorbance of sample }}{\text { Absorbance of standard }} \times \frac{\text { concentration of standard }}{1}
$$

\subsection{Determination of Alanine Amino Transferase (ALT) Level}

\subsubsection{Principle}

This was determined by the method of Reitman and Frankel [13]. ALT is measured by monitoring the concentration of pyruvate hydrazine formed with

$$
\text { 2,4 - dinitrophenylhydrazine } \alpha \text { - oxoglutarate }+\mathrm{L}-\text { alanine } \stackrel{G P P}{\longrightarrow} \mathrm{L}-\text { glutamate }+ \text { Pyruvat }
$$

\subsubsection{Procedure}

To two test tubes labeled blank, and sample, $0.1 \mathrm{rnl}$ of distilled water, $0.1 \mathrm{ml}$ of serum samples was measured into each tube respectively and $0.5 \mathrm{ml}$ of the substrate reagent $\left(\mathrm{R}_{1}\right)$ was added to each of the tubes which was mixed and incubated for 30 minutes at $37{ }^{\circ} \mathrm{C}$. Then $0.5 \mathrm{ml}$ of dinitrophenyl hydrazine solution $\left(\mathrm{R}_{2}\right)$ was mixed and allowed to stand for 20 minutes at $20-25{ }^{\circ} \mathrm{C}$ and finally $5 \mathrm{ml}$ of sodium hydroxide $(0.4 \mathrm{M})$ was added to each tube, mixed and the absorbance of the sample (A sample) was read against the reagent blank after 5 minutes using spectrophotometer at $546 \mathrm{~nm}$, and the concentration was obtained.

\subsection{Statistical analysis}

The data obtained from the test were subjected to one- way analysis of variance (ANOVA). Significant differences were obtained at $\mathrm{P}<0.05$ by Boniferroni multiple range test. The results were expressed as mean \pm standard error of mean (SEM). This was estimated using Statistical Package for Social Science (SPSS) version 23. 


\section{Results and discussion}

Table 1 Mean serum Liver Enzymes of Albino rats treated with combined extracts of Andrographis paniculata leaves and Zingiber officinale Rhizoids

\begin{tabular}{|l|l|l|l|}
\hline Group/dosage & AST (IU/L) & ALP (IU/L) & ALT (IU/L) \\
\hline Group $1(100 \mathrm{mg} / \mathrm{kg})$ & $170.80 \pm 20.09$ & $50.40 \pm 5.15$ & $17.20 \pm 4.80$ \\
\hline Group $2(200 \mathrm{mg} / \mathrm{kg})$ & $135.20 \pm 15.38$ & $64.80 \pm 9.00$ & $15.80 \pm 2.84$ \\
\hline Group $3(300 \mathrm{mg} / \mathrm{kg})$ & $119.60 \pm 24.38$ & $64.20 \pm 13.26$ & $25.20 \pm 5.68$ \\
\hline Group $4(400 \mathrm{mg} / \mathrm{kg})$ & $109.20 \pm 19.55$ & $98.40 \pm 13.26$ & $41.20 \pm 4.80$ \\
\hline Group 5 (control) & $125.60 \pm 18.98$ & $86.00 \pm 16.66$ & $33.20 \pm 5.12$ \\
\hline
\end{tabular}

Diagnostic enzymology entails the use of enzymes in the prognosis and diagnosis of various diseases. This is achievable through the understanding of the sources of enzymes and certainty of the assay in the serum or plasma. Detection of an abnormal high level of these enzymes in the serum may be an indication of defectiveness of the origin of cells [14]. Enzyme assays have been of immense clinical significance in the diagnosis of liver, heart, gastrointestinal tract, muscles and bones diseases. The liver is one of the most rudimentary organs that engaged in the biotransformation of xenobiotics and elimination from the body [15]. Generally, analysis of the activities of some basic liver functions, enzymes in the plasma or serum offer useful information on the integrity of tissues after being exposed to certain pharmacological or environmental toxic agents. These enzymes are usually liver markers whose plasma concentration above the homeostatic limits could be associated with various forms of disorders which affect the functional integrity of the liver tissues. Orthodox pharmacological preparations which are usually used for the treatment, further accelerate the toxication of the liver [16]. In this situation, a great reliance has been evident on plant formulations [17]. The present study evaluated the effects of the combined ethanol extracts of Andrographis paniculata leaves and Zingiber officinale rhizoids on the serum levels of AST, ALT and ALP in albino wistar rats.

Statistically, the results showed Changes in serum AST levels in all the treated groups compared with the control, but showed significant decrease in group 4 treated with $400 \mathrm{mg} / \mathrm{kg}$ compared to group 1 treated with $100 \mathrm{mg} / \mathrm{kg}$. This is similar to the report of Nagaraya and Knshna [16], that Andrographis paniculata leaf extract decreases serum AST levels in rats. The mean serum AST level was however, greater than its normal range of 5-45IU/L, though no significant difference was recorded between the treated groups and the control.

Furthermore, even though there were increase in the mean serum AST in treatment groups 1 and 2 compared with its control, there was no adverse effect of the extracts on liver integrity and other organs and tissues associated with the enzyme. The marked decrease at $400 \mathrm{mg} / \mathrm{kg}$ signified the extract potential in the treatment of liver diseases, myocardial infection, muscle disorders, since elevated levels of AST is recorded in these disorders [18].

The results of ALP revealed significant decrease at $100 \mathrm{mg} / \mathrm{kg}$ compared with $400 \mathrm{mg} / \mathrm{kg}$ and control. Similarly, a significant decrease at $100 \mathrm{mg} / \mathrm{kg}, 200 \mathrm{mg} / \mathrm{kg}$ and $300 \mathrm{mg} / \mathrm{kg}$ were observed compared to $400 \mathrm{mg} / \mathrm{kg}$. The marked decrease within the normal range (30-130IU/L) could be traced to the important medicinal constituents of the extracts particularly the antioxidant molecules. Belquet [18], reported that the main mechanism of liver damage is by bioactivation of reactive oxygen species and free radicals that elicit oxidative stress [19]. It is believed that the potent antioxidant molecules in the extracts counter balances the effects of the free radicals. The results of the ALT further revealed significant decrease at $100 \mathrm{mg} / \mathrm{kg}$, and $200 \mathrm{mg} / \mathrm{kg}$, extracts administration compared to the control. Also, significant decrease at $100 \mathrm{mg} / \mathrm{kg}, 200 \mathrm{mg} / \mathrm{kg}$ and $300 \mathrm{mg} / \mathrm{kg}$ treatment were observed compared to $400 \mathrm{mg} / \mathrm{kg}$. The mean serum ALT in this study falls within the normal range of 5-40IU/L. ALT is more specific marker of hepatocellular injury because it occurs exclusively in the liver and it is markedly increased in liver cirrhosis, and liver cell necrosis [14]. The decrease in serum ALT in this study is advantageous as the combined extracts could be used for the treatment of hepatic dysfunction. However, elevated serum ALP and ALT levels at $400 \mathrm{mg} / \mathrm{kg}$, compared with other treatment doses showed toxic potential of the extracts at higher doses, Therefore, it is important to state categorically that since there is an increase in ALP level at this dose, it could still not be confirmed liver damage because according to Odutola [20], ALP and AST originate from different tissues, such as liver, bone, intestine and pancreas. Purportedly, the increase might be from other sources other than the liver. 


\section{Conclusion}

Based on the results obtained in this study, it could be concluded that the combined extract of the two plants studied exerted hepatoprotective effect on the experimental animals and could be advantageous in treating hepatic disorders.

\section{Compliance with ethical standards}

\section{Acknowledgments}

We wish the acknowledge the contributions of technologist in Department of Science Technology (Biochemistry unit) Akwa Ibom State Polytechnic and Mr Aniekan Akpakpan, Department of Chemistry Akwa Ibom State University,

\section{Disclosure of conflict of interest}

We declare that there is no conflict of interest to disclose

\section{Statement of ethical approval}

All experimental procedures involving animal were conducted in accordance to organization for Economic Co-operation and development guidelines and Canadian council on animal care Guidelines and Review.

\section{References}

[1] Pieters L, Vlietinek AJ. Biological Isolation of Pharmacologically Effect of A. paniculata, against Cadmium induced Toxicity in Male Wistar Rats. Toxicology International. 2005; 15(1): 21-25.

[2] Baluna MJ, Kinghorn AD. Drug Discovery from Medicinal Plants. Life Science. 2005; 78(2): 431-441.

[3] Farnsworth NR, Soejart DD. Global Importance Medical Plant, the Conversion of Medical Plant. UK: Cambridge University Press. 1991; 25-51.

[4] Kim KS, Park SU, Kim KM, Yang CJ. Mistletoe on Ecological Facts and Conceptual. Schattailerlay. 2011; 5: 251-253.

[5] Mayo CO. A review on Medical Prospective of A. paniculata. Journal of Pharmacology and Scientific Actions. 2010; 10(5): $1-5$.

[6] Wen, J. C., Sheeja, K., Shihab, P. K. \& Kuttan, G. (2010). "Antioxidant and Anti-inflammatory Activities of the Plant Andrograhis paniculata Seeds". Immunopharmacology and Immunotoxicology, 28(1), 129-140.

[7] Grazanna R, Lindmark L, Frondoza C. Ginger a Herbal Medicinal Product with Broad Anti-inflammatory Action. Journal of Medical Food. 2005; 8(2): 125-132.

[8] Omoya FO, Akhariayi FC. Mixture of Honey and Ginger Extracts for Antibacterial Assessment on some Clinical Isolate. International Journal on Pharmaceutical and Biomedical Research. 2011; 2(1): 39-47.

[9] Al-Taglaway RM, El-Bastawesy AM, Mormen MG, zekry KZ. Antioxidant Activity of the Volatile oils of Zingiber officinale. Journal of Medicine. 2011; 1(1): 1-8.

[10] Akhani SP, Vishwakarma SL, Goyal RK. Anti-diabetic Activity of Z. offiinale in Streptozocin-Induced Type 1 Diabetic Rats. Journal of Pharmacology. 2004; 56(1): 101-105.

[11] Balunas, M. J and Kinghorn, A. D. (2005). Drug Discovery from Medicinal Plants Life Science. 78 (2): 431 -441

[12] Englehant A. Randox Laboratory Kit for the Determination of the Enzyme "P-Nutophenylphosphatase". American Journal of Chemical Pathology. 1970; 16: 431- 435.

[13] Reitman, M. D and Frankkel, S (1957). A colorimetric method for the determination of Serium Enzymes. American Journal of Clinical Pathology. 28 (1): 56 - 63

[14] Uboh FE, Okon IE, Ekong M. Effect of Aqueous Extract of Psiduim guajara Leave on Liver Enzymes, Histological, Integrity and Heamatological Indices in Rats. Gastroenterology Research. 2010; 3(1): 32-38.

[15] Sagar R, Bhaji A, Toppo FA, Sahoo HB. Comprehensive Review on Herbal Drugs for Hepatoprotective of 21st Century. International Journal of Nutritional Pharmacology and Neurological Diseases. 2014; 4: 191-197. 
[16] Nagaraya Y, Knshna V. Hepatoprotective Effect of the Aqueous Extract and 5-Hydroxy, 7, 8, 2-Trimethoxy Fiabone of A. paniculata in carbon Tetrachloride Treated Rats. Achievement in the Life sciences. 2016; 10: 5-10.

[17] Summer M. Hypoglycemic and Hepatoprotective Effects of Bernoma amygdalina and its effect of some Biochemical parameters in alioxan-induced Diabetic Male Albino Rats. Science Journal of Biochemistry. 2000; 5: 312-320.

[18] Belguet AP. Investigation of the Phytochemicals, Antioxidant, and Antimicrobial Activity of the A. paniculata Leaves and Stem Extracts. Advances in Bioscience and Biotechnology. 2010; 8: 149-162.

[19] Bedi O, Bijjem KV, Kumar P, Gauttam V. Herbal Induced Hepatoprotective and Hepatotoxicity: A Critical Review. Indian Journal of Physiological Pharmarcology. 2016; 60: 6-21.

[20] Odutola GP. A review on Medical Prospective of Z. Officinale. Journal of Pharmacological and scientific Actions. 2014; 314-324. 